\title{
Lessons from Afghanistan
}

\author{
Rory Stewart
}

Published online: 9 November 2012

(C) NYREV, Inc. 2012

The Dark Defile: Britain's Catastrophic Invasion of Afghanistan, 1838-1842 by Diana Preston Walker, 307 pp., $\$ 28.00$

Diana Preston's The Dark Defile describes the disastrous occupation of Afghanistan by Britain from 1839 to 1842 . This is a well-known story-depicted in grand nineteenth-century canvases (Remnants of an Army), 1960s comedies (Flashman), and a flurry of books with Victorian titles, published or republished to coincide with our current Afghan mess: Signal Catastrophe, Crimson Snow, The Last Man, Retreat and Retribution, Butcher and Bolt. Most of the books remind us that the British "Army of the Indus" swaggered into Kabul from India in 1839; that the general's personal baggage had been loaded on 260 camels; that behind the lancers in their scarlet cloaks and plumed shakos trotted a pack of hounds, which had been led through the arid horrors of the Bolan Pass in order to hunt foxes in the Hindu Kush; and that the Afghans were soon watching ice-skating and giving advice to British women on their geraniums.

The British had invaded to replace the Afghan king, because they felt he was becoming too close to the Russians, and that Afghanistan could have been used by Russia to threaten British India. By November 1841, Sir Alexander Burnes, the British political official responsible for Kabul, congratulated his superior, Sir William Hay Macnaghten, on the perfect tranquility of the country. A day later, Burnes was hacked down in the flames of his burning mansion; a week later, the British garrison was under siege; on December 23 Macnaghten's mutilated corpse was hung from a butcher's hook in the bazaar; and on January 6 the British army began its retreat.

With the permission of the New York Review of Books.

R. Stewart ( $\square)$

New York, USA

e-mail: ceeun@ceeun.org 
Some 15,000 soldiers and camp followers marched out of their compound through the snow, heading for the British garrison at Jalalabad. Some died of exposure, others were taken hostage or escaped, but most were killed. Five thousand men, women, and children died as they struggled through a five-mile gully outside of Kabul, picked off by muskets or cut down with swords. On January 13, sentries looking for the Army of the Indus saw a single wounded man moving across the plain. Dr. William Brydon was what remained of the Army of the Indus.

This "signal catastrophe" is illuminated by an astonishing range of contemporary sources, far more than exist for any classical or medieval conflict, and indeed for many more recent campaigns. You can read Colin Mackenzie's description of a naked Indian baby, wide-eyed and abandoned on the snow-plain, at the beginning of the retreat, and you can still admire Mackenzie's full-length portrait in the British National Army Museum (he has curled mustaches and is wearing the robes of a Persian prince). You can read the diary of Lady Sale, whose tough, unblinking account of the retreat, written on tattered sheaves of cheap paper, with her own deletions to conceal stories of cannibalism, survives in the British Library. And in family collections and regimental museums you can peer at thousands of smudged and occasionally blood-stained letters, entries, and memoranda, written by the civilian and political officers killed during the uprising.

Preston makes use of many of these sources, providing a fair summary of the events. But she neglects the equally exciting Afghan accounts. They do not match the laconic realism of the British diaries-some include comic stories of sorcery and miracles-but they reveal Afghan perspectives, of which Europeans, then and now, seem to have been largely unconscious.

The only contemporary historian to use these sources to illuminate fully the Anglo-Afghan war is William Dalrymple, whose book will be published early next year. ${ }^{1}$ Dalrymple's dealings with the book dealers in Kabul led him to the memoirs of the Afghan king; contemporary Afghan chronicles; two serious works by nineteenth-century Afghan historians; and two contemporary poems, written in the sonorous verse of ancient Persian epic. Dalrymple has been able to describe many facts not contained in the British sources, the sophistication of Afghan court culture, and the clearly religious flavor of much of the resistance.

I was struck also by the emphasis in Dalrymple's Afghan sources on a rape committed by a British soldier in Kandahar, which passes unnoticed in the British accounts, but to which the Afghans attribute much of their early rage. All these sources, however, focus on the mistakes made by the British, and tempt historians such as Preston to believe that the disaster was the result of two things: avoidable military errors and the pernicious interference of civilian "political officers."

The first explanation might be described as the view of George Macdonald Fraser, whose fictional antihero, Flashman, says of the British commander:

If you had taken the greatest military geniuses of the ages, placed them in command of our army, and asked them to ruin it utterly as speedily as possible, they could not - I mean it seriously — have done it as surely and swiftly as he did.

\footnotetext{
${ }^{1}$ Return of a King: the first Anglo-Afghan war and the birth of the Great Game (Knopf, February 2013).
} 
This view was echoed in most contemporary British accounts, and reflects the fact that almost all were written by soldiers (Lady Sale is the notable exception, though she has very military prejudices). Almost all assert that the army could have avoided disaster if it had marched immediately into the city of Kabul, avenged the murder of the resident, and crushed the insurgency. It should, they say, have used night attacks to seize strategic positions and to defend its outlying forts and stores, moving its base to the more defensible royal castle, and holding out there, rather than retreating. In other words, they suggest that the situation could have been saved with a clear strategy, good leadership, sufficient resources, and enough troops. And they foster the idea-as the Soviet military did in 1988 - not only that they were not defeated, but that they could have won outright if they had not been let down by bad planning, logistics, and tactics, and then been withdrawn by cowards.

Even at the time, this was a view highly appealing to the policymakers. The president of the India Council, John Cam Hobhouse, assured the House of Commons: "It is a military defeat-nothing more. It has nothing to do with the policy...." Foreign Secretary Lord Palmerston added, "There is no reason [why] we shall not be able to recover in Afghanistan the same position as we occupied before the disaster happened."

All the sources put the greatest blame for the British disaster, however, on the shoulders of the civilian political officers, in particular Macnaghten, the envoy, and his deputy Burnes. When the commander in chief of the Indian army (quoted approvingly by Preston) gave his reasons for the failure in 1842, for example, he blamed "making war with a peace establishment...giving undue power to political agents... [and] want of forethought and undue confidence in the Afghans on the part of Sir William Macnaghten."

Macnaghten was criticized for cutting the subsidies to Afghan chiefs, for removing their influence over army recruitment, and for his contradictory attempts to bribe and eliminate rebel leaders. Burnes was blamed for seducing Afghan women. Both were blamed for having dragged Britain into the disaster, for undermining military goals for "political reasons," and for ignoring the reports of the uprising that eventually killed them. Military witnesses saw this as the inevitable result of a British system in which overpromoted, pretentious civilians were allowed to interfere in military matters. As General William Nott, who commanded at Kandahar throughout the campaign, remarked: "If a man is too stupid or too lazy to drill company, he often turns sycophant, cringer to the heads of departments and is made a 'Political,' and of course puts the government to enormous expense, and disgraces the character of his country."

But all of this was then-and remains_-grossly unfair to men who, having been killed in the campaign, were unable to defend themselves. In fact, the political officers, in or around the Afghan adventure, were part of an elite cadre of highly experienced specialists. Macnaghten was an extraordinary linguist and a unique authority on Indian legal texts. Among other political officers, Eldred Pottinger led much of the brilliant defense of Herat against a Persian attack, and Henry Rawlinson rode seven hundred miles across Persia in six days, and was the first man to decipher Persian cuneiform. Almost all had undertaken solo journeys of exploration, opening 
entirely new routes into Central Asia. Alexander Burnes in particular was tough, endlessly curious, witty, imaginative, and courageous.

It is true that, to the fury of military officers like General Nott, the "politicals" who survived could not avoid a knighthood, a governorship, an honorary degree, a medal from a learned society, or even a parliamentary seat, but it was not easy to survive: in the few months following the uprising in Kabul, Charles Stoddart and Arthur Conolly, two political officers, were thrown in a pit in Bokhara and then beheaded. Eldred Pottinger ("the hero of Herat") and Arthur Conolly's brother John died of fever; Alexander Burnes and his brother were hacked down in Kabul; and William Macnaghten was killed at point-blank by a prince at a meeting.

But they did not die because of naiveté. Macnaghten's whole later career had relied on a culture in which hosts protected diplomats and guests (it is still difficult to understand why the Afghan prince murdered the defenseless envoy). Burnes would have done better to withdraw from his unprotected residence. He remained at his post not because he was inexperienced but because he felt he could neither keep his reputation nor do his work if he fled when threatened.

All these men knew that the walls of the royal castle would have offered more protection than their pathetic camp. But it would have insulted Afghans, and made the king appear even more of a puppet, to place British troops among the king's women in the royal palace. Ignoring such political and cultural issues and the king's wishes would have inflamed resistance more rapidly. (And indeed when, in 1879, having "learned the lessons" from the first Afghan war, the next British envoy insisted on taking up residence in the royal castle, he was killed almost immediately.) It was not the civilian political officers' fault that the British were insufficiently bold and active in challenging insurgents or recapturing strategic positions. The political officers pressed for all these things, arguing that decisive action was vital for the credibility of the occupation. They were continually overruled by General William Elphinstone and General John Shelton, whose professional military judgment was that it was too dangerous to fight in narrow streets, or mount night attacks, or to try to hold out in Kabul. Generally, the problem was not that the military placed too much emphasis on the advice of political officers, but too little.

It is a mistake, however, to put the blame for the disaster on either the generals or the political officers. Whatever decisions were made, there would have been no happy ending. A foreign army isolated in Kabul, propping up an unpopular ruler in the face of a growing insurgency, could not succeed. To maintain security, they needed to create a new Afghan army, which required taxation and expenditure. This created enemies and required a resource base, which Afghanistan did not have. They therefore relied on enormous - and unsustainable - amounts of foreign funding (which in turn fueled corruption).

They needed to win the support of the population if they were to defeat the insurgency and build a legitimate state; but the population would not support a weak, corrupt state in the middle of an insurgency. To reassure the nationalists, the foreign force had to convince them they were leaving; and to reassure the supporters of the British, the foreign force had to convince them they were staying. Such political problems could not be solved with more troops. They were all (to use a 
British policymaker's phrase) "the inevitable consequence of our position in Afghanistan."

The most interesting and least well explored question, therefore, is why did the policymakers choose to invade Afghanistan in the first place? It is disappointing that Preston-like almost every other historian-does not make this question more of the focus of her book. This is not for lack of sources. We have access to the secret correspondence from the "Political and Secret department," the reports submitted by British agents in Persia, Herat, and Kabul, and the original version of the public papers, with the handwritten annotations of the British foreign secretary, Lord Palmerston: we know more about the policy process than we know about many modern wars. And the reasons and the arguments of the policymakers, contained in these documents, are as eloquent as they are catastrophic.

The decision to invade Afghanistan was made in India by the governor-general, Lord Auckland, and Macnaghten (who was then foreign secretary to the Indian government). It was championed in London by Palmerston and John Hobhouse. The Indian decision-makers feared instability among the independent states of Sindh and were intimidated by the Sikh kingdom of the Punjab and its large professional army. (At the time, the frontier of British India was close to the modern Indian-Pakistani border.) They perceived Afghanistan, beyond the Punjab, as an unstable, fragmented state. Beyond Afghanistan, they saw an expanding Russia as a mortal threat to British India, which could only be contained by creating a buffer of proBritish rulers in Afghanistan and the Punjab. The existing ruler of Afghanistan, Dost Mohammed, seemed too weak, too close to Russia, and too hostile to the Punjab for their purposes, so they decided to replace him with Shah Shuja-a former Afghan king, now in exile in British India-on the grounds that Shah Shuja was "the legitimate ruler," and popular with the Sikhs. All these measures, were perceived, in Hobhouse's words, as "indispensable for the very safety of our Eastern Empire." Preston records such views but does not analyze them.

The theories were senseless. Informed and influential people said so at the time. First, the threat posed by Russia was grotesquely exaggerated. As Disraeli observed in his great speech criticizing the war in 1842, British India was "an empire separated on the east and west from any power of importance by more than 2,000 miles of neutral territory, bounded on the north by an impassable range of rocky mountains; and on the south by 10,000 miles of ocean." (The Russian attempt to cross even the very first section to Khiva, in 1840, led to the loss of an entire army.)

Second, the Punjab, which the policy-makers treated as a permanent cornerstone of regional security, was in truth a new, fragile kingdom, which collapsed, and was then invaded and occupied by the British a few years later. Third, as Burnes argued, Dost Mohammed, who the policymakers portrayed as weak and treacherous, was in fact a very promising potential ally who preferred "the sympathy and friendly offices of the British." Fourth, there was almost no conceivable legal and moral justification for the invasion. It was, in the politician Lord Aberdeen's words in 1839 , "as rash and impolitic as it was ill-considered, oppressive and unjust."

Finally, as many pointed out before the invasion, the policymakers completely underestimated the practical problems of occupying Afghanistan. One ex-governor general of India, Lord William Bentinck, called it "an act of incredible folly." His 
brother the Duke of Wellington predicted that the soldiers would be drawn into a "perennial march into that country," and that the difficulties would begin when the military operations were ended. Mounstuart Elphinstone, the greatest living authority on Afghanistan, focused on nationalist resentment:

If you send 27,000 men... and can feed them, I have no doubt you will take Kandahar and Kabul...; but for maintaining [the new king] in poor, cold, strong, and remote country, among a turbulent people like the Afghans,... it seems to me to be hopeless... The Afghans were neutral...they will now be disaffected and glad to join any invader to drive you out.

Why did Palmerston and the senior officials in the capitals ignore such detailed, broad-ranging, and authoritative criticisms?

We may want to believe that the policymakers were stupid, ignorant, or evil. But they were not. The governor-general, Lord Auckland, was a calm, diligent administrator, and his secretariat included the men reputed to be the cleverest in British India. Lord Palmerston had long experience as secretary of war for nineteen years, and foreign secretary, almost continuously, for a further nine years, before the invasion. Having designed the policy of the invasion, Macnaghten went out to Kabul personally to implement it, where he demonstrated admirable energy, a deep respect for Asian culture and religion, and a sincere affection for the locals.

The uncomfortable truth is that experienced, energetic, knowledgeable men, surrounded by vigorous and thoughtful staff and excellent advice, were nevertheless seduced by superficial premises, inadequate reasoning, and unjustified conclusions, and launched a war on the most flimsy of theories. As a new member of the British Parliament, I am perhaps oversensitive to the irresistible momentum of policy, but it seems astonishing just how elegantly and comprehensively the policymakers convinced themselves and others to undertake a disastrous intervention.

No amount of negative reporting from the ground could shake their confidence. Macnaghten continued to believe, in defiance of all evidence, that the Afghan ruler was popular. And each of the advocates of British strategy-Auckland, Macnaghten, Hobhouse, and Palmerston-found distinctive ways of belittling or marginalizing his opponents. Lord Auckland dealt with the warnings of his predecessor, Metcalfe, by assuring him that no decisions had been made, and then suddenly that the decisions had already been made, and it was too late to quibble ("It is little good in politics to be long looking back on footsteps that are already passed"). Macnaghten convinced himself that critics in London had been too long out of the region. And that Burnes, his critic and representative in Kabul, had been too long in the region. When Burnes warned of the growing insurgency, Macnaghten argued that Burnes was only being pessimistic because he wanted his job, and wanted to take credit for any success.

Hobhouse implied that his critics were either slandering honorable men or were simply ignorant of the larger strategic context. In Parliament in 1842 he treated his opponent Disraeli with contempt: "If the hon. Member knows so little of what passes in London, how can he know what has passed in India?" He backed his position with an intimidating list of detailed facts about British trade on the Indus, 
the legitimacy of the rulers of the Sind, import statistics at the port of Calcutta, and the stability of Egypt and the Ottoman Empire.

Palmerston chose to play on national pride and national fears. He and his colleagues raised the specter of a strong Afghan state attacking Peshawar (in modern Pakistan); of a weak Afghan state, which could not prevent others from attacking Peshawar; and of the threat to the reputation of Britain. Palmerston said of the invasion: "The vigorous decision will do us the utmost service.... The world has begun to think that England had really become...a "power known only by tradition." Such anxieties have haunted other superpowers in the cold war and beyond, and we might characterize Palmerston's national security rhetoric, in modern jargon, as exploiting a fear of a domino effect, a rogue state, or a failed state, and fear for national credibility. It led him to neglect diplomatic solutions in favor of extreme military action. In Disraeli's words, to lurch from a "fatal inertness to a still more terrible activity."

But the most troubling aspect of their parliamentary rhetoric is the way that, having dragged Britain into the war, the policymakers tried to make it seem almost impossible to leave. Palmerston portrayed withdrawal as "a want of moral courage" and an unthinkable humiliation, which would leave the world a much more dangerous place.

Rely upon it, that if you abandon that country it will get into other hands; and though you may, by such a course, escape from some little present difficulty, and save some little present expense, the day will come when you will be compelled to re-occupy that country at an infinitely greater expenditure of money, and at an infinitely greater sacrifice of life than would enable you now to retain it.

(In fact, Britain did not go back in for another forty years, and when it did, it was again pursuing an exaggerated threat, and found only humiliation.)

All this was so successful that much of the British media, led by the Morning Chronicle, continued to champion the Afghan war even after the horrors of 1842. Palmerston was able to avoid the many calls for a parliamentary inquiry into the disaster, and he so successfully avoided taking responsibility for the invasion that he went on to become prime minister, a position in which he was able to display again in the Indian Mutiny/Rebellion (which his Afghan policies had helped to foster) exactly the same combination of unscrupulous optimism and jingoistic overreaction that he had shown a decade earlier.

Nevertheless - after a brief expedition to free the prisoners (and more shamefully to take revenge-through a massacre in Istalif and the destruction of the seventeenth-century heart of Kabul) - the new government of Robert Peel did the right thing: it pulled out completely. Two and a half years after the British invaded, there was not a single British soldier or civilian left in Afghanistan; their old enemy Dost Mohammed took over again as ruler, on a British pension; and he remained a reliable ally for the next twenty years. The confidence and wisdom of this final withdrawal is almost as incomprehensible as the folly that underlay the invasion.

The political debate in London reveals how immensely difficult-intellectually, morally, and politically - it was for Peel and his colleagues to withdraw. They had 
to tackle the dense thicket of expert opinions on regional security, which had grown up to justify the intervention. They were forced to challenge parts of the military establishment and contradict the generals (many of whom continued to insist that all that was needed was a clearer mission, more resources, and more troops). They took the risk that withdrawal would leave Afghanistan in civil war, and that they would be accused of shirking their moral responsibility to improve conditions there. They accepted the humiliation of seeing their enemy, who they had invaded to topple, take back control. They ignored the media screams about cowardice and national disgrace. They faced down the fears about national security and loss of credibility. And by doing so, they avoided being trapped by the guilt, paranoia, and irrational momentum of war.

Their ability to withdraw at all was in part a tribute to an old culture of experience and criticism, to which Peel wisely responded. The men who carefully exposed the folly of the Afghan policy — and in some cases like Sir Charles Metcalfe kept doing so over a decade or more-were vilified and sidelined by the interveners. But they continued to patiently answer every fear, counter every empirical claim, sketch out every risk, and develop the arguments that made withdrawal, though always difficult, at least conceivable. All this was helped by the unique expertise and language ability that then existed in government institutions, and in particular among the much-despised political officers.

This experience gave the critics of British policy not only the instinct that the occupation would fail, but the confidence and credibility to say so. And they were emboldened by a culture that reveled in challenging poor policy with rhetoric and rudeness (this was one of the things that Palmerston hated in the Indian civil service and tried to eliminate with his later reforms, when he said he would rather have second-rate obedient people than first-rate independent minds).

Apportioning responsibility for the Afghan intervention-resisting the temptation to condemn the policymakers on the basis of their (many) impulsive comments, weighing the mistakes in Kabul against the mistakes in London-is difficult for a historian. But it is possible. The model account of the war, Sir John Kaye's History of the War in Afghanistan - still by far the best—was published within nine years of the retreat, when many of the participants were still alive. Kaye's history draws on his own experience as an Indian soldier and administrator in order to imagine, and consider in the smallest detail, each tiny decision to deploy a gun on Bemaru, to halt for supplies, to withdraw from a fort, or to accept an offer of a negotiation. He forces readers to think, reconsider, and live through each of the impossible choices of the campaign.

Preston has not attempted this kind of history. She excuses her neglect with the remark that "the political and moral aspects [are] both more subjective and more difficult to analyse." This reluctance to investigate the contradictory detail of policy decisions, and to assess the moral and intellectual foundations of the occupation, is also characteristic of almost every recent book on the Afghan invasion beginning in 2001. It may also be symptomatic of our culture. It is striking that, although as much time has passed since our invasions of Iraq and Afghanistan as had passed when Kaye wrote his book 160 years ago, we have yet to produce anything on those conflicts that matches his objectivity and empathy. Our inability to acknowledge the 
inherent paradoxes of occupation, to recognize an impossible mission, to expose the flimsiest of national security arguments, or to accept the limitations of government institutions abroad (the prerequisites for any withdrawal), seems a weakness not just of our historians but also of our policymakers.

Many recent accounts of the first Anglo-Afghan war, the second British humiliation in 1879, and that of the Soviet Union in 1979 (of which the best is Rodric Braithwaite's wonderful Afgansty, steeped in interviews and primary research) have tempted readers to echo British Prime Minister Harold Macmillan's favorite line: "Rule number one in politics is: never invade Afghanistan." There is in fact little in common between the Afghanistan of Shah Shuja and the Afghanistan of Hamid Karzai. If the first Anglo-Afghan war tells us anything it is not about Afghanistan, but about ourselves. It is a parable less of "an unchanging East" than of an unchanging West. 